\title{
Linguistic Ability and Critical Thinking of Undergraduate Literature Students
}

\author{
Scarlett O'Hara Sanchez ${ }^{1}$, Maria Luisa S. Saministrado ${ }^{2 *}$, PhD \\ ${ }^{I}$ English Instructor, Misamis University, Oroquieta City, Philippines \\ ${ }^{2}$ Professor of English, College of Arts and Sciences, Department of English Language and Literature, Xavier \\ University, Philippines
}

*Corresponding Author: Maria Luisa S. Saministrado, Professor of English, College of Arts and Sciences, Department of English Language and Literature, Xavier University, Philippines

\begin{abstract}
This study examined the relationship between linguistic ability and critical thinking of undergraduate literature students. It attempted to answer the levels of students' critical thinking in terms of Bloom's taxonomy and the relationship between students' linguistic ability and critical thinking skills. Using the descriptive research design, this study administered two sets of questionnaires on linguistic ability and critical thinking skills. Although English has been the medium of instruction in the Philippine universities for decades now, the scores reveal that the students' level of critical thinking needs improvement. The linguistic ability of students shows that it has not been fully developed as proficiently as desired. There is a significant relationship between linguistic ability and critical thinking on knowledge, comprehension, analysis, synthesis, and evaluation but not on application. The need to re-focus more on higher level thinking activities particularly on synthesis and evaluation is suggested to improve considerably the students' critical thinking skills and linguistic abilities in English.
\end{abstract}

Keywords: Linguistic Ability, Critical Thinking, Bloom's Taxonomy, Undergraduate Students, English Proficiency

\section{INTRODUCTION}

English proficiency in writing is linked to the learners' linguistic ability and critical thinking. It is achieved if learners have the ability to make extended texts that contain suitable meta-discourse attributes like exemplifiers and connectives as well as varied vocabulary and syntactic structures, to make use of several patterns for organization like description and narration, and to effectively include other persons' ideas in their own writing (Barkaoui, 2007). Moreover, they have the ability to compose that is suggestive of the ability to tell or retell information in a narrative and descriptive form, or change information into new ideas (Mehrabi, 2014).

Undergraduate students are expected to have developed their writing proficiency in English. However, acquiring writing proficiency can be a challenge because different competencies such as linguistic, cognitive, and socio cultural are considered. According to Sadiyah (2017), students with lower level thinking skills appear to be using limited vocabulary and making more errors in syntax. Some were reported to have written outputs that were below average characterized by ambiguity and inconsistency in their choice of words (Gow, 2012).

Acquiring writing proficiency is not only mastering the technical and formal aspect of writing. It is also about the ability to think critically on vocabulary choice, reasoning applied with original thought, and language usage (Ofte, 2017). Good writing therefore is a reflection of good critical thinking (Golpour, 2014). Critical thinking is a type of thinking skillfully responsible of the inherent formation of thinking, and imposes standards on the intellect (Adeyemi, 2012). It includes skills in conceptualizing, employing, scrutinizing, harmonizing, and judging information brought about by study, experience, reflection, reasoning, or communication as a guide to belief and action, evaluating information to reach an answer or conclusion (Peter 2012 cited by Muhlisin et al., 2016; Almubaid, 2014). Critical thinking is involved in the writing process as students generate ideas through problemsolving that uses a range of linguistic and cognitive abilities. These abilities produce and develop ideas and enhance verbal and written expressions (Nur Indah \&Kusuma, 2016). 
There are students in tertiary education who write professionally. They are more analytical and evaluative in writing a composition. This calls for more investigation to determine whether a higher critical thinking level is involved or not and explore the relationship between linguistic ability in writing and critical thinking.

This study is anchored on the Cognitive Theory of Vygotsky. Vygotsky believes that language is one of the most important psychological tools that effect children's cognitive development. He identifies three different stages in the children's use of language. Firstly, language is an essential factor for communication (social speech). Next, children begin to use egocentric or private speech to control their own thinking. The last stage is language development where children use verbal thoughts to guide their thinking and their actions. Vygotsky claims that language and thought first become independent after them being interdependent. He suggests that attainment of a new word is the beginning of the development of a concept. The acquisition and use of language play a primary role in children's developing intellectual abilities.

This study examined the relationship between the linguistic ability and critical thinking levels of undergraduate students in Misamis University for the academic year 2017-2018. Particularly, it sought answers to (1) the level of critical thinking of students in terms of the various levels of thinking on knowledge, comprehension, application, analysis, synthesis, and evaluation; (2) the level of critical thinking of students by demographic characteristics in terms of age, year level, and high school graduated from; (3) the level of critical thinking of students by department of Liberal Arts and Education and Applied Courses; (4) the level of students' linguistic ability; (5) and the relationship between linguistic ability and critical thinking levels of students.

The findings of this study will offer significant information educators may consider as basis to enhance students' linguistic ability and critical thinking skills. It will provide information to students on the value of knowing both linguistic ability and critical thinking as factors for high achievement in tertiary education. This means that they can achieve excellent academic performance by developing their linguistic ability and critical thinking skills. This study can be a baseline on understanding their capacity in the course. It will give teachers insights on the level of linguistic ability and critical thinking of their students and in understanding how they can improve academic performance. Moreover, the result of the study will provide school administrators with firsthand basis in the preparation of instructional materials that improve the students' linguistic ability and critical thinking. Their understanding of this study will give better directions to teachers to aim for quality education. It will also supply curriculum planner's important ideas for policy formulation that enhances both the students' linguistic ability and critical thinking. The findings of this study may guide researchers to other similar studies in the future. They can apply the concept and see the importance of linguistic ability as well as critical thinking skills in their research work.

The students' level of critical thinking was evaluated basing on the Taxonomy of Bloom which comprises knowledge, comprehension, application, analysis, synthesis, and evaluation. Bloom's Taxonomy is divided into lower level thinking which comprises knowledge and comprehension and higher level of thinking which consists of application, analysis synthesis, and evaluation. Students' linguistic ability was evaluated based on their composition writing with a focus on the five criteria: content, organization, paragraph development, grammar and mechanics, and style. There were 115 students who were enrolled in Literature in the second semester of academic year 2017-2018. They come from the departments of the institution namely: Liberal Arts and Education and Applied Courses comprising the departments of Business Administration, Criminology, and Information Technology served as respondents in the study. There may be other linguistic abilities and dimensions of critical thinking, but this investigation was restricted only to those enumerated above.

\section{RESEARCH METHODOLOGY}

The study utilized the descriptive type of research in determining, describing, and in documenting the relationship between students' linguistic ability and critical thinking skills.

\subsection{Research Setting}

This study was conducted at Misamis University, Oroquieta City, Mindanao, Philippines during the academic year 2017-2018. The university has only more than one thousand population. Considering the small number of enrollees in every program offered, the administrators decided to use 
"department" instead of college. The university is composed of the departments of Liberal Arts and Education, Business Administration, Information Technology, and Criminology. In this study, the departments of Business Administration, Information Technology, and Criminology comprised the Applied Courses.

\subsection{Research Respondents}

The respondents of the study are the students enrolled in literature classes of Misamis University. These students belong to the four departments for the academic year 2017-2018. These are: Liberal Arts \& Education, Business Administration, Criminology, Information Technology (Applied Courses) with the total number of 115 enrollees.

Table1. Departments with the Corresponding Number of Enrollees in Literature

\begin{tabular}{|l|l|}
\hline \multicolumn{1}{|c|}{ Department } & \multicolumn{1}{|c|}{ Enrollees } \\
\hline Liberal Arts \& Education & 22 \\
\hline Business Administration, Criminology, Information Technology (Applied Courses) & 93 \\
\hline Total & 115 \\
\hline
\end{tabular}

\subsection{Research Instruments}

To obtain the desired data, the researchers required the respondents to write one or two paragraphs on the topic "What is unusual about your family" to test their linguistic ability and a ready-made questionnaire of Saministrado (2005) as the principal instrument for critical thinking skills. The questionnaire focuses on a literary piece entitled "Boy Left Behind" written by a Filipino author, Ligaya Vitoria Reyes. The construction of questions is based on the levels of questioning espoused by Bloom which includes the levels of critical thinking: knowledge, comprehension, application, analysis, synthesis, and evaluation. Every level of questions contains 10 points.

\subsection{Scoring Procedure}

Table 2 shows that the total number of items for critical thinking is 60 and total number of points in each level is 10 .

Table2. Total Number of Items for Critical Thinking and Total Number of Points in each Level

\begin{tabular}{|l|l|}
\hline \multicolumn{1}{|c|}{ Points per Level } & \multicolumn{1}{c|}{ Description } \\
\hline $9-10$ & High \\
\hline $7-8.99$ & Above Average \\
\hline $5-6.99$ & Average \\
\hline $0-4.99$ & Below Average \\
\hline
\end{tabular}

The rubric with a total number of 20 points was used for scoring the linguistic ability of students.

Table3. Rubric with a Total Number of Points of 20 was used for Scoring the Linguistic Ability of Students

\begin{tabular}{|l|l|}
\hline \multicolumn{1}{|c|}{ Points per Level } & \multicolumn{1}{c|}{ Description } \\
\hline $16-20$ & Exemplary \\
\hline $11-15$ & Above Average \\
\hline $6-10$ & Average \\
\hline $0-5$ & Poorly \\
\hline
\end{tabular}

\subsection{Ethical Considerations}

To uphold the ethical aspect of the study, the approval of the President of Misamis University, was obtained prior to the conduct of the research. After that, the approved letter from the President and program heads of the different departments was sought to allow for the conduct of the research. The respondent-students were made to sign the informed consent forms as a way of ensuring that they understood what it meant to participate in this research. Informed consent gave the respondents the freedom to participate and the leeway to withdraw at any stage. Names were optional for the sake of confidentiality and anonymity in the reporting of the findings of the study.

\subsection{Data Gathering Procedure}

Before the questionnaire was administered to the respondents, permission was obtained from the President of Misamis University. Upon approval of the president, a letter of request was written for 
the program heads of the four departments involved. When the request was granted, the survey was conducted to the respondents. Before the distribution of the questionnaire, the respondents were informed about the purpose of the research and then asked them to answer the questionnaire. Questions were entertained from the respondents. The respondents were given a total of one (1) hour to answer the critical thinking test. The one hour test included 30 minutes for the reading and another 30 minutes to answer the questions. They were given five (5) minutes extension to review for their answers.

\subsection{Statistical Treatment of Data}

Since this study attempted to identify, describe, and document the level of students' critical thinking, the statistical tools, Mean and Pearson r, were employed. Mean was used to describe the level of the linguistic ability and critical thinking of the student-respondents and to determine the level of students' critical thinking by demographic characteristics and according to their department. Pearson $r$ was used in determining the significant relationship between linguistic ability and critical thinking of the students.

\section{LiTERATURE REVIEW}

The related literature and studies aided the notions upheld in the present investigation. All literature and studies provide baseline data to substantiate its content and to serve as a blueprint in the critical analysis and interpretation of the data being gathered.

Linguistic ability is a widely used and frequently misused concept. It is an ambiguous term in educational thought and foreign language literature. Most frequently, 'linguistic ability' is defined in terms of the achievement of certain language goals which are deemed worthiest by those setting the goal. The meaning of 'linguistic ability' tends to be quite arbitrary. For example, the teacher who believes the worthiest goal of language study to be oral communication would define a student's linguistic ability in terms of his achievement in speaking and comprehending spoken language. On the other hand, the teacher who believes the worthiest goal of language learning to be comprehending the thoughts conveyed through literature would define 'linguistic ability' in terms of a student's performance in comprehending and conveying literary thought. While the definition of the term appears ambiguous, the effects of its usage are not. Language students who finish their courses with feelings of inadequacy are considered to possess 'marked linguistic ability' and those remaining considered 'average' or 'poor'.

Since linguistics is defined as relating to language and ability as acquired proficiency in a particular work or activity, proficiency in writing can be equated to linguistic ability. The ability to write is mainly a cognitive provocation because writing demands a test involving memory, language, and thinking abilities simultaneously (Kellogg, 2001 as cited by Nikou, 2015). Learning to write is undisputedly connected with the student's intellectual development. Hence, it is possible to assume the notion that a child is possibly to be born with a built-in mental properties and mechanisms in his brain. These mechanisms provide the development of intellectual processing. These processes undeniably leads to language acquisition (Solonchak \& Pesina, 2014). Chomsky (1966 as cited by Barman, 2014) defines language as an expression of the human mind. Metaphorically, language is a mirror of the mind.

Chomsky believes that a long list of rules is not needed when mastering language because children have inherent knowledge of super rules. Therefore, children can direct on their mental switches than learn a thousand rules. The brain possibly is comprised with a program which permits to acquire limitless number of statements from a limited number of words. The brain supplies the ability to change a thought into a series of words of an existing language (Pesina \& Solonchak, 2014). The theory of Chomsky states that children are noticeably to be 'hard-wired' to have grammar. Consequently, early in life, children have a greater ability to acquire languages. If the ability is not used for a long time, it will vanish or deteriorate with maturation. However, if the ability is always used, their abilities for further language learning will continue to be complete throughout life (Major, 2014).

An ability, such as linguistic, is considered as special, as it is presumably determined by a specific brain anatomy or greater brain plasticity in foreign language learners (Biedron, A., \&Szczepaniak, 2009). The linguistic ability on writing is a cognitive movement which demands the writer to have 
control in several variables like grammar, content, mechanics, and vocabulary (Khoshsima, 2016). Higher education students are expected to acquire the variables mentioned above. Moreover, they are expected to acquire the components of writing such as the writing of letters in the alphabet at logical speed, writing the word spelling correctly, remembering appropriate choice of words and positioning them in sentences, utilizing correct punctuation marks, applying sentence-connectors and sequence signals such as articles and pronouns, assembling ideas in logical sequence, and so on (Al-Ahdal et al., 2014).

Students' improvement in their writing ability goes together with the improvement in their ability of expressing deeper levels of thoughts. Thus, among language skills, writing is the most important in relation to critical thinking (Nikou, 2015). Critical thinking is considered a manner of thinking that is focused on giving a decision to believe or to do (Ennis, 2010). Critical thinking is employed in giving judgment on an information, discussing the causes, and providing solutions to unknown problems (Thomas, 2011), so that each individual is able to understand any content or information on a particular thing (Zane, 2013). Critical thinking is a significant issue in education. Thus, the improvement of critical thinking skills should be one of the main goals of educators from elementary to college. By giving assistance to students to become better thinkers, students will become better writers and vice-versa (Sharadgah, 2014).

Bloom's taxonomy of general objectives (1956) is generally accepted in the teaching of critical thinking. This taxonomy emphasizes the cognitive domain. His six-level description of thinking has been extensively adapted and utilized in unlimited contexts ever since. His list of cognitive processes is properly arranged from the most simple, the retrieval of knowledge, to the most complex, giving judgments about the value and worth of an idea. Cognitive taxonomy consists of six skill levels of learning, which have increasing complexity beginning with knowledge, comprehension, application, analysis, synthesis, and evaluation.

Knowledge relates to the simple remembering of facts. It is defined as the recollecting of previously learned material. It constitutes the lowest level of learning outcomes in the cognitive domain. In this level, students search for objective answers to the $4 \mathrm{~W}$ 's and $1 \mathrm{H}$ as "Who", "What", "When", "Where", and "How". Before comprehension or analysis, knowledge comes first. It is the first step students must take when they begin their critical look into a piece of text.

Grouping, comparing, describing, or even explaining of facts comprise comprehension. It is the ability to easily get the meaning of the material and goes just beyond. It involves what the student has learned and interprets it into one's own words. Comprehension is the lowest level of understanding and it is an important ability to obtain before being able to utilize the knowledge for any useful purpose. It contains classification, estimation, explanation, illustration, prediction and summary.

Constructing on knowledge and comprehension, a student moves onto application which is the ability to apply previous acquired knowledge to a new scenario. Application needs a higher level of understanding than comprehension. Application is always a major struggle for an educator because while one might have the enormous ability to comprehend obtainable knowledge, the question is always, "How do I apply this to what I am doing?" This level helps learners to apply, change, complete, defend, interpret, and translate.

The fourth skill level is analysis which requires the student to examine any supporting evidence and the resulting conclusion in an effort to reach a reasonable conclusion. In this area, the learning outcomes require an understanding of both the content and the structural form of material. This is where a student has to become like an archaeologist, exploring, comparing, contrasting, investigating, researching, inferring, and examining. Analysis is often used to prove whether something is correct. Lastly, it is often used to demonstrate the relevancy, usefulness, and qualities of knowledge learned. Without proper probing into knowledge, we will not know how it can be applied to whatever we are doing in society.

With sufficient experience in the area of analysis, a student can learn to develop his own reasonable solutions; this is referred to as synthesis. Learning outcomes at this level stress creative behaviors with a major emphasis on the formulation of new patterns or structures. It aids in bringing the student into new stages of adapting, combining, developing, experimenting, imagining, predicting, and speculating. 
Synthesis calls for the students' ability to try to look at the bigger picture of whatever they have learned. This is where creativity plays a huge role in a student's acquisition of some useful knowledge or skill. It gives students a chance to suggest their own ideas and solutions to the material they have learned. The learners become real participants of what they read or they engage actively in a more direct way. Synthesis offers learners a chance to create their own unique solutions or apply the theory in their work or personal life. Lastly, synthesis gives learners a chance to form new perspectives. The learners are no longer just students, but those who seriously challenge existing ideas. Synthesis is not emphasized enough in schools. It is an educator's responsibility to instill in the learners to not just to obtain knowledge, but to give them the motivation to think on their own and how they can contribute to what they have read, seen, or heard.

The apex of Bloom's taxonomy is evaluation, where the students create qualitative and quantitative judgments based on evidence and think critically. Evaluation focuses on the ability to judge the value of material for a given purpose. Criteria are the bases of student judgement. In evaluation, the learning outcomes are the highest in the cognitive hierarchy because they involvethe elements of knowledge, comprehension, application, analysis, and synthesis which enablethe students to assess, command, conclude, critique, and support their findings (Bloom, 1956).

Students need to learn to work at all of these levels of thinking because critical thinkers work at the higher levels of Bloom's revised taxonomy (Black \& Ellis, 2010).Bloom's Taxonomy organizes the students thinking and learning emphasizing on the highest level of thinking. In far too many learning environments, the learning never goes beyond the very beginning levels of learning and the explanation is very simple - the lower levels are easy to quantify and evaluate. The lower levels are important as they are steps to higher level learning (Ozola, 2013). According to Bloom (1956) and Anderson and Krathwohl (2002), the higher level learning is vital because it is through the higher levels of thinking that students begin to have a real relationship with learning and the world around them.

Veeravagu et al. (2008) conducted an exploration of the relationship between the students' performance and the level of thinking processes basingon Bloom's taxonomy when answering a reading comprehension paper. The obtained results revealed that the participants' performances were varied depending on the level of the thinking process involved. The participants had higher scores in low levels of the thinking process while lower scores on the most complex levels. Many researchers felt that teachers over-emphasized the lower level of mental processing at the expense of the higher levels in their instruction (Alwine, 2014).

It is vital to recognize that new abilities cannot be learned quickly. Understanding the essence of time, real processes bring some real, concrete time to happen. The time cannot be stretched (Fell, 2012). It is not sensible to express that the same abilities can be achieved in some short period of time.

The studies which have been cited investigated on variables of linguistic ability on writing and critical thinking. The present research used the reading as bases of the framework of this study. They have contributed much not only on the formulation of the questionnaire but also in the interpretation of the gathered data.

\section{Presentation, Analysis, and Interpretation of Data}

Analysis and interpretations of the linguistic ability serve as determinants of the critical thinking skills among the students of Misamis University. Data are arranged according to the statement of the problem of the study.

\subsection{The Students' Levels of Critical Thinking based on Bloom's Taxonomy}

Bloom's critical thinking helps educators to identify the intellectual level where students are capable of working. The lower levels are knowledge, and comprehension while the highest levels are application, analysis, synthesis, and evaluation. Universities desire that students develop the highest levels of critical thinking. It is not known which level student respondents fall according to the critical thinking of Bloom's. Hence, the above-mentioned critical thinking skills are taken into consideration in this present study. 
Table4. Distribution of the Respondents' Level of Critical Thinking

\begin{tabular}{|l|l|l|}
\hline \multicolumn{1}{|c|}{ Levels of Thinking } & \multicolumn{1}{c|}{ Mean } & \multicolumn{1}{c|}{ Description } \\
\hline Knowledge & 7 & Above Average \\
\hline Comprehension & 6 & Average \\
\hline Application & 7 & Above Average \\
\hline Analysis & 5 & Average \\
\hline Synthesis & 5 & Average \\
\hline Evaluation & 4 & Below Average \\
\hline
\end{tabular}

Table 4 shows the respondents' level of critical thinking. It can be gleaned in the table that respondents were above average in knowledge which is considered the lowest level of critical thinking and the simplest intellectual ability. Evidently, respondents were good in remembering the obtained facts from previously learned information in the text. Knowledge level is considered the starting point in developing complex thinking. Pineda affirms that knowledge is an important skill for keeping and recapturing new linguistic information.

Comprehension concentrates on how far a student is able to grasp the meaning of information and presents problems in their own words. As can be seen in Table 1, respondents demonstrated average level of critical thinking. This means respondents encountered difficulties in comprehending information or presenting problems in their own words and in utilizing the knowledge for any useful purpose.

The application level requires the participants to apply what they have learned in new situations. As shown in Table 4, the respondents displayed average level which implies that the respondents appeared to be competent in using previous knowledge in new situations.

In this cognitive level, the respondents are expected to segregate component parts from a whole. In this level, the respondents analyzed patterns and organized ideas. Table1 shows that the respondents were able to use analysis on an average level indicating a need to develop the critical thinking process on analysis.

Synthesis is the opposite of analysis and, therefore, the respondents put component parts together to form a whole. This level provokes the respondents to put component parts together to form a whole. This level tests the respondents to make new patterns based on what they have learned. They are required to construct original ideas in order to propose alternative solutions through the combination of elements in new ways. The results obtained presented an average level which signifies that respondents lack the critical thinking process on synthesis and its application in the writing task.

Evaluation is the most complex among the levels of critical thinking because it requires the respondents to make judgments about rules, principles or ideas. As shown in Table 1, the results indicated that respondents were below average implying the respondents' need for improvement. Since evaluation is the most complex, educators must focus on the harnessing of this level on their students.

When looking at the results, it can be observed that respondents' performance were varied depending of the thinking process involved. The results are in agreement with Veeravagu's findings (2008) that the lower levels of thinking process obtained the highest scores, while the complex levels garnered lower scores. This means that the more complex the thinking level, the lower the score.

\subsection{The Level of Critical Thinking of Students by Demographic Characteristics}

Demographic variables may intervene the critical thinking of students. Hence, demographic variables such as age, year level, and high school graduated from are looked into in this study.

Table5. Level of Critical Thinking of Respondents by Demographic Characteristics in Terms of Age

\begin{tabular}{|l|l|l|}
\hline \multicolumn{1}{|c|}{ Age } & \multicolumn{1}{|c|}{ Knowledge (mean) } & \multicolumn{1}{c|}{ Description } \\
\hline $16-17$ & 6.61 & Above average \\
\hline $18-19$ & 6.73 & Above average \\
\hline 20 and above Age & $6.78 \quad$ Comprehension & Above average \\
\hline \multicolumn{1}{|c|}{ Description } \\
\hline $16-17$ & $6.20 \quad 6.20$ & Average \\
\hline 20 and above & 6.11 & Average \\
\hline
\end{tabular}


Linguistic Ability and Critical Thinking of Undergraduate Literature Students

\begin{tabular}{|c|c|c|}
\hline Age & Application & Description \\
\hline $16-17$ & 6.62 & Above average \\
\hline $18-19$ & 6.82 & Above average \\
\hline 20 and above & 7.22 & Above average \\
\hline Age & Analysis & Description \\
\hline $16-17$ & 5.26 & Average \\
\hline $18-19$ & 5.47 & Average \\
\hline 20 and above & 5.22 & Average \\
\hline Age & Synthesis & Description \\
\hline $16-17$ & 4.67 & Average \\
\hline $18-19$ & 4.56 & Average \\
\hline 20 and above & 4.89 & Average \\
\hline Age & Evaluation & Description \\
\hline $16-17$ & 3.93 & Below average \\
\hline $18-19$ & 4.67 & Average \\
\hline 20 and above & 5.11 & Average \\
\hline
\end{tabular}

Table 5 shows that the knowledge and application levels of critical thinking are above average in all ages of the respondents from 16 to 20 above. The results signify that the ability to recall the basic facts in the text and to apply what they have learned in new situations are stronger in all ages of the respondents. Knowledge and application are developed among respondents because teachers overemphasized the knowledge and application levels of mental processes at the expense of the other higher levels of thinking in their instruction (Bissell \& Lemmons, 2006).

It is noticeable in Table 5 that the critical thinking of the respondents in all age groups on the two higher level skills which are analysis and synthesis do not differ. The three age groups exhibited an average level of critical thinking signifying that their intellectual ability is within the norm in analysis and synthesis. However, older students, 18-19 and 20 above years old, display above average level of critical thinking in evaluation than younger students, 16- 17 years old. This means that younger students struggle in making judgments and decisions than older students. The result is an affirmation of Jacob's (1995 cited by Perry et al., 2014) statement about age as a second predictor of the level of critical thinking.

Table6. The Level of Critical Thinking of Respondents by Demographic Characteristics in Terms of Year Level

\begin{tabular}{|c|c|c|}
\hline Year level & Knowledge (mean) & Description \\
\hline $2^{\text {nd }}$ year & 6.74 & Above average \\
\hline $3^{\text {rd }}$ year & 6.42 & Average \\
\hline $4^{\text {th }}$ year & 7.33 & Above average \\
\hline Year level & Comprehension & Description \\
\hline $2^{\text {nd }}$ year & 6.33 & Average \\
\hline $3^{\text {rd }}$ year & 5.83 & Average \\
\hline $4^{\text {th }}$ year & 6.67 & Above average \\
\hline Year level & Application & Description \\
\hline $2^{\text {nd }}$ year & 6.56 & Above average \\
\hline $3^{\text {rd }}$ year & 7.00 & Above average \\
\hline $4^{\text {th }}$ year & 7.50 & Above average \\
\hline Year level & Analysis & Description \\
\hline $2^{\text {nd }}$ year & 5.26 & Average \\
\hline $3^{\text {rd }}$ year & 5.44 & Average \\
\hline $4^{\text {th }}$ year & 5.67 & Average \\
\hline Year level & Synthesis & Description \\
\hline $2^{\text {nd }}$ year & 4.68 & Average \\
\hline $3^{\text {rd }}$ year & 4.44 & Below average \\
\hline $4^{\text {th }}$ year & 5.33 & Average \\
\hline Year level & Evaluation & Description \\
\hline $2^{\text {nd }}$ year & 3.88 & Below average \\
\hline $3^{\text {rd }}$ year & 5.00 & Average \\
\hline $4^{\text {th }}$ year & 5.50 & Average \\
\hline
\end{tabular}

As seen in Table 6, the 4th year students have the stronger critical thinking levels in knowledge, comprehension, application, and analysis. They can retrieve, recall, or recognize relevant knowledge 
from memory and can easily grasp the meaning of materials. Moreover, they can apply what was learned to a novel situation in another setting. They have the ability to distinguish between facts and inferences and determine how the parts relate to one another. There is evidence that students in the higher year level have an advantage especially on the lower level of thinking and higher thinking on application and analysis.

The $2^{\text {nd }}$ and $3^{\text {rd }}$ year students display above average level of critical thinking both in application and analysis only. However, $3^{\text {rd }}$ year students show below average in synthesis while the $2^{\text {nd }}$ year in evaluation. This finding confirms the findings of Dianti where students were poor in their critical thinking on synthesis and evaluation. Synthesis and evaluation have not been given emphasis in all subjects of the respondents. It might be because the students were not engaged with the teaching and learning process which practiced and demanded the students to think critically when the students were in early education level. Or the teachers focus more on activities and tasks that merely require lower levels of thinking among the students.

Table7. The Level of Critical Thinking of Respondents by Demographic Characteristics in Terms of High School Graduated from

\begin{tabular}{|c|c|c|}
\hline High School Graduated from & Knowledge (mean) & Description \\
\hline Public & 6.63 & Above average \\
\hline Private & 6.82 & Above average \\
\hline High School Graduated from & Comprehension & Description \\
\hline Public & 6.23 & Average \\
\hline Private & 6.05 & Average \\
\hline High School Graduated from & Application & Description \\
\hline Public & 6.86 & Above average \\
\hline Private & 6.27 & Average \\
\hline High School Graduated from & Analysis & Description \\
\hline Public & 5.31 & Average \\
\hline Private & 5.45 & Average \\
\hline High School Graduated from & Synthesis & Description \\
\hline Public & 4.52 & Average \\
\hline Private & 5.18 & Average \\
\hline High School Graduated from & Evaluation & Description \\
\hline Public & 4.29 & Below average \\
\hline Private & 4.41 & Below average \\
\hline
\end{tabular}

The data in Table 7 show that respondents from both private and public high school possess an above average level of critical thinking on knowledge. The students find it easy to retrieve information from the text. They are encouraged to practice memorizing certain important information, thus knowledge which requires lower order thinking is being developed. On the other hand, evaluation level has been taken for granted in the primary and secondary high school both private and public. The students were found below average level in evaluation. There is simply a need to strengthen the higher order thinking activities to improve their evaluation level.

Students coming from private and public high school can possibly have higher thinking if they have enough exposure to learning opportunities where students not only recognize the importance of memorizing but also giving judgment, the highest thinking level they are supposed to learn that could lead them to think critically.

\subsection{The Level of Critical Thinking of Students by Department}

The department in an institution may intervene the critical thinking of students. Henceforth, the Department of Liberal Arts and Education and Applied Courses are considered in this study.

Table8. Level of Critical Thinking of Respondents by Demographic Characteristics as to Department of Liberal Arts and Education

\begin{tabular}{|c|l|l|}
\hline \multicolumn{1}{|c|}{ Department } & \multicolumn{1}{c|}{ Knowledge (mean) } & \multicolumn{1}{c|}{ Description } \\
\hline Arts \& Education & $6.82 \quad$ Comprehension & Above average \\
\hline Applied & $6.63 \quad$ & Above average \\
\hline Department & \multicolumn{2}{c|}{ Description } \\
\hline Arts \& Education & $6.05 \quad$ Average \\
\hline
\end{tabular}




\begin{tabular}{|c|c|c|}
\hline Applied & 6.23 & Average \\
\hline Department & Application & Description \\
\hline Arts \& Education & 6.27 & Average \\
\hline Applied & 6.86 & Above average \\
\hline Department & Analysis & Description \\
\hline Arts \& Education & 5.45 & Average \\
\hline Applied & 5.31 & Average \\
\hline Department & Synthesis & Description \\
\hline Arts \& Education & 5.18 & Average \\
\hline Applied & 4.52 & Average \\
\hline Department & Evaluation & Description \\
\hline Arts \& Education & 4.41 & Below average \\
\hline Applied & 4.29 & Below average \\
\hline
\end{tabular}

As displayed in Table 8, the students of the Department of Liberal Arts and Education as well as in the Applied Courses have the ability of recognizing important information in the text which facilitates high critical thinking on the knowledge level. Students who have the ability in memorizing will always excel in examinations that need recall or recognition.

Students in applied courses like Information Technology, Business Administration and Criminology are found to be above average in application level than the students in Liberal Arts and Education. It is easier for students in Applied Courses to choose and apply rules, concepts, laws, and theories they have learned. Nevertheless, both students in Liberal Arts and Education and Applied Courses could not assess information and offer decision. It sad to note that students failed to develop their critical thinking on giving judgment. As stated by Thomas (2011) critical thinking is used to pass judgment on any information, explain the reasons, and solve the problem of the unknown.

Over the years, teachers have not highlighted students' evaluative ability. Even in college, students still show the same below average ability on evaluation level. If left undeveloped, higher critical thinking on evaluation will never be attained. There are some students who require special help and directed training to improve their critical thinking skills and there are others who seem to mature on evaluative abilities by themselves.

\subsection{The Level of Students' Linguistic Ability}

The linguistic ability on writing which is a cognitive activity and requires the writer to control on different areas of writing (Khoshsima, 2016) is regarded in this study.

Table9. Level of Students' Linguistic Ability

\section{Students' Linguistic Ability}

\begin{tabular}{|c|c|}
\hline Mean & Description \\
\hline 9.19 & Average \\
\hline
\end{tabular}

As reflected on Table 9, the linguistic ability of students on writing is average. The writing outputs of students in regard to organization were coherently and logically organized. However, some points were misplaced and ideas strayed from the topic. Content revealed that thinking and reasoning applied with original thought on a few ideas. Students tried to use transitions but not used throughout their writing. Readers of their writing can follow the progress of the main points because most spelling, punctuation, and grammar were correct but errors still remained. Students only applied some variety in sentence patterns or structures.

The results would mean that the students were able to absorb the rules on writing imparted to them by the English teachers. However, the former have just enough ability on writing of the English language, as their ability in writing is just average. Students responded differently to different learning situations, which implied that students' ability may be improved by modifying the learning environment to fit their needs and psychological profile. Simply stated, it suggests that either the students be accommodated to the teaching or the teaching to the students.

\subsection{The Relationship between the Linguistic Ability and Critical Thinking of Students}

Acquiring writing proficiency is not only mastering the technical and formal aspect of writing but also the ability to think critically on vocabulary choice, attention to logic and reasoning, and language usage (Ofte, 2017). In this study, the linguistic ability of students is significantly related to their critical thinking skills. 
Table10. The Correlation (Pearson r) between Linguistic Ability and Critical Thinking Skills

\begin{tabular}{|l|l|l|l|}
\hline \multicolumn{2}{|c|}{ Correlations } \\
\hline Linguistic Ability & Pearson Correlation & Linguistic Ability & Critical Thinking \\
\hline & Sig. (2-tailed) & 1 & .799 \\
\hline & $\mathrm{N}$ & & .000 \\
\hline Critical Thinking & Pearson Correlation & 115 & 115 \\
\hline & Sig. (2-tailed) & .799 & 1 \\
\hline & $\mathrm{N}$ & .000 & \\
\hline$* *$ Correlation is significant at the 0.01 level (2-tailed) & 115 & 115 \\
\hline
\end{tabular}

As shown in table 10, the correlation (Pearson $\mathrm{r}$ ) between linguistic ability and critical thinking skills is .799 (or .80) which is statistically significant at the .01 level. The positive correlation means that students who have high linguistic ability are also likely to have high critical thinking skills.

The findings of the study confirms on Nikou's study (2015) which states that students' improvement in their writing ability goes together with the improvement in their ability of expressing deeper levels of thoughts. Thus, among language skills, writing is the most important one in relation to critical thinking (Nikou, 2015).

Specifically, the linguistic ability of students has significant relationship on knowledge, comprehension, analysis, synthesis and evaluation of students. The sig. values are less than 0.05 . It can also be interpreted that linguistic ability is a good predictor for knowledge, comprehension, analysis, synthesis and evaluation of students. On the other hand, linguistic ability has no significant relationship on the application as a level of critical thinking of students.

\section{FINDINGS AND CONCLUSION}

\subsection{Findings}

\subsubsection{The Level of Students in Terms of the Various Levels of Thinking by Bloom}

In the lower levels of thinking, the students were found above average level of critical thinking in knowledge while average in comprehension level. In the higher level of thinking, the students were found above average in application and average in analysis and synthesis but below average in evaluation.

\subsubsection{The Level of Critical Thinking of Students by Demographic Characteristics}

As to their age, the students whose ages were 18-19 and 20 and above exhibited above average level of critical thinking in knowledge and application but average in comprehension, analysis, synthesis, and evaluation. Even the students who were 16-17 years old showed above average in knowledge and application and average in comprehension, analysis, and synthesis but were below average in evaluation.

As to their year level, the $4^{\text {th }}$ year students had above average level in knowledge, comprehension, application and analysis but average in synthesis and evaluation. The $3^{\text {rd }}$ year students were only above average in application and analysis but average in knowledge, comprehension, and evaluation. They struggled in the synthesis level of critical thinking where they fell on below average level. The $2^{\text {nd }}$ year students were found above average in knowledge, application, and analysis but average in comprehension and synthesis. They were struggling in the evaluation level of critical thinking.

As to the type of high school graduated from, the students both in private and public had above average level in knowledge and application but average in comprehension, analysis, and synthesis. They encountered difficulty in the evaluation level.

\subsubsection{The Level of Critical Thinking of Students by Department}

The students both in the Department of Liberal Arts and Education and Applied Courses unveiled above average level in knowledge but only Applied Courses were above average in application. Students in both categorization of departments were average in comprehension, analysis, and synthesis. Nevertheless, their evaluative ability was below average.

\subsubsection{The Linguistic Ability of Students}

The linguistic ability of students on writing was average which shows that content development indicates thinking and reasoning applied with original thought on just a few ideas. The writing is 
coherent and logically organized, but some points remain misplaced and ideas strayed from the topic. The use of transitions was evident but they were not used throughout the composition. And as to paragraph development, the main points of their composition were present with limited detail and development although some critical thinking was observed. There were a few errors in spelling, punctuation, and grammar while college level usage of some variety in sentence patterns, diction, and rhetorical devices was evident.

\subsubsection{Significant Relationship between Linguistic Ability and Critical Thinking}

A relationship exists between the linguistic ability and critical thinking of students. Therefore, there is a significant relationship between linguistic ability and critical thinking levels on knowledge, comprehension, analysis, synthesis, and evaluation. However, application is not significantly related to the linguistic ability of students. This means that application as a higher level of critical thinking exists independently because the performance of one's linguistic ability will depend on the clarity of new tasks assigned or instructions given to students.

\subsection{Conclusion}

Although the English language is being taught in the Philippines for decades now, the results are nowhere near the expected outcomes. The linguistic ability of students has not been fully developed as proficiently as desired. Thus, when they were required to write a paragraph, their composition showed lack of content, organization, grammar and mechanics, and style.

The over emphasis on the knowledge level of critical thinking does not challenge students to think critically. Hence, they scored more on the lower levels of thinking than on higher thinking.

It is evident that there is a significant relationship that exists between linguistic ability and critical thinking. If the linguistic ability of students is well developed, it can help them to think critically. However, it is vital to recognize that new abilities cannot be learnt quickly because they require concrete time and a thorough planning and preparation for educators to consider tasks or activities that promote higher order thinking in the students.

\section{REFERENCES}

[1] Adeyemi, S. B. (2012). Developing Critical Thinking Skills in Students: A Mandate for Higher Education in Nigeria. European Journal of Educational Research, 1(2), 155-161. Retrieved on May 5, 2018 from https://files.eric.ed.gov/fulltext/EJ1086348.pdf

[2] Al-Ahdal, A. A. M. H., Alfallaj, F., Al-Awaied, S., \& Al-Hattami, A. (2014). A comparative study of proficiency in speaking and writing among EFL learners in Saudi Arabia. American International Journal of Contemporary Research, 4(2), 141-149. Retrieved on May 15, 2018 from ttps://www.researchgate .net/profile/Abdulghani_Al-Hattami/-and-Writing-among-EFL-Learners-in-Saudi-Arabia.pdf

[3] Almubaid, H. (2014). Applying and Promoting Critical Thinking in Online Education. The International Conference on E-Learning in the Workplace, June 11th-13th, New York, NY, USA.

[4] Alwine, S. (2014). A case study examining the explicit method of critical thinking instruction in a community college English Classroom (Doctoral dissertation, George Mason University).

[5] Anderson, L. W., \& Krathwohl, D. R. (Eds.). (2001). A taxonomy for learning, teaching and assessing: A revision of Bloom's Taxonomy of educational objectives: Complete edition, New York : Longman. Retrieved on May 30, 2017 from https://sustainabledevelopment.un.org/content/documents/full_report. pdf\#page=37

[6] Assaly, I. R., \&Smadi, O. M. (2015). Using Bloom's taxonomy to evaluate the cognitive levels of master class textbook's questions. English Language Teaching, 8(5), 100. Retrieved on May 16, 2018 http://www.ccsenet.org/journal/index.php/elt/article/viewFile/47951/25737

[7] Barkaoui, K. (2007). Teaching writing to second language learners: Insights from theory and research. TESL Reporter, 40(1), 35-48.

[8] Bloom, B.S. (Ed.). Engelhart, M.D., Furst, E.J., Hill, W.H., Krathwohl, D.R. (1956).Taxonomy of Educational Objectives, Handbook I: The Cognitive Domain. New York: David McKay Co Inc.

[9] Chernigovskaya, T. V., \&Vasileva, O. (2015). What Genes and Brain Can Tell Us of How Symbolic Cognition Appeared in the Human Mind. In EAPCogSci. Retrieved on May 5, 2018 from http://ceurws.org/Vol-1419/paper0052.pdf

[10] Ennis, R. (2010). Twenty-one Strategies and Tactics for Teaching Critical Thinking. Most Recently Published Version: (2011). Inquiry: Critical Thinking Across the Disciplines, 26, 2, 5-19. Retrieved on May 30, 2017 from http://criticalthinking.net/howteach.html. 
[11] Fell, E. V., \&Lukianova, N. A. (2015). British Universities: International Students' Alleged Lack of Critical Thinking. Procedia-Social and Behavioral Sciences. Vol. 215: International Education and CrossCultural Communication, Problems and Solutions,(IECC 2015).-Amsterdam, 2015., 215, 2-8. Retrieved on 20 , 2018 from http://earchive.tpu.ru/bitstream/11683/33650/1/dx.doi.org-10.1016-j.sbspro.2015.11. 565.pdf

[12] Golpour, F. (2014). Critical Thinking and EFL Learners' Performance on Different Writing Modes. Journal of Pan-Pacific Association of Applied Linguistics, 18(1), 103-119.

[13] Indah, N. \&Kusuma, A. (2016) Factors Affecting the Development of Critical Thinking of Indonesian Retrieved on May 29, 2018 from https://www.researchgate.net/publication/309375926_Factors_Affecting_ The_Development_of_Critical_Thinking_of_Indonesian_Learners_of_English_Language

[14] Khoshsima, H., \&Sayadi, F. (2016). The effect of virtual language learning method on writing ability of Iranian intermediate EFL learners. Advances in Language and Literary Studies, 7(2), 192-202. Retrieved on June 1, 218 from http://journals.aiac.org.au/index.php/alls/article/viewFile/2194/1933

[15] Krathwohl, D. R. (2002). A revision of Bloom's taxonomy: An overview. Theory into practice, 41(4), $212-218$.

[16] Major, C. A. (2014). The effect of age on second language acquisition in older adults. Retrieved on May 20, 2018 from https://scholarsarchive.byu.edu/cgi/viewcontent.cgi? article=4972\&context=etd

[17] Mehrabi, N. (2014). The effect of second language writing ability on first language writing ability. Theory and Practice in Language Studies, 4(8), 1686.Retrieved on May 16, 2018 from https://pdfs.semantic scholar.org/pdf

[18] Muhlisin, A., Susilo, H., Amin, M., \&Rohman, F. (2016, June). Improving critical thinking skills of college students through RMS model for learning basic concepts in science. In Asia-Pacific Forum on Science Learning and Teaching (Vol. 17, No. 1, pp. 1-24). The Education University of Hong Kong, Department of Science and Environmental Studies. Retrieved on May 20, 2018 from http://www.eduhk.hk/apfslt/download/v17_issue1_files/muhlisin.pdf

[19] Nikou, F. R., Bonyadi, A., \&Amirikar, N. (2015). Investigating the relationship between critical thinking skills and the quality of Iranian intermediate TEFL students' writing. Advances in Language and Literary Studies, 6(2), 57-64.

[20] Ofte, I. (2014). English academic writing proficiency in higher education: Facilitating the transition from metalinguistic awareness to metalinguistic competence. ActaDidactica Norge, 8(2), Art-17. Retrieved on June 3, 2018 from https://journals.uio.no/index.php/adno/article/viewFile/1142/1021

[21] Ozola, S. (2014). Views on Taxonomy and Learning. Education in a Changing Society, 1, 152-159. Retrieved on May 15, 2018 from https://scholar.google.com/scholar.

[22] Paul, R., \& Elder, L. (2006). The thinker's guide to the art of Socratic questioning. Dillon Beach, CA: Foundation for Critical Thinking

[23] Pesina, S., \& Solonchak, T. (2015). Concept in Cognitive Linguistics and Biocognitive Science. ProcediaSocial and Behavioral Sciences, 192, 587-592. Retrieved on June3, 2018 from https://ac.els-cdn.com

[24] Pesina S., Solonchak T. (2014). The Image as an Initial Element of the Cognitive Understanding of Words // International Science Conference: International Conference on Language and Technology (June 19-20). World Academy of Science, Engineering and Technology. International Science Index Vol: 8, No:6, Part XI, Venice, Italy, 2014. - pp. 994-999.

[25] Peter, E. (2012). Critical Thinking: Essence for Teaching Mathematics and Mathematics Problem Solving Skills. African Journal of Mathematics and Computer Science Research, 5(3), 39-43.

[26] Sa'diyah, H. (2017). Improving Students' Ability in Writing Descriptive Texts through a Picture SeriesAided Learning Strategy. The English Teacher, 19. Retrieved on May 5, 2018 https://journals.melta .org.my/index.php/tet/article/viewFile/269/166

[27] Saministrado, Maria Luisa S. (2005). Verbal Interactions in Literature Classes: Implications on Ignatian Paradigm for Teaching.” Unpublished Dissertation: Xavier University, Cagayan de Oro City.

[28] Solonchak, T., \& Pesina, S. (2015). Language Ability and Word Functioning. Procedia-Social and Behavioral Sciences, 192, 447-452. Retrieved on May, 2018 from https://ac.els-cdn.com

[29] Thomas, T. (2011). Developing First Year Students' Critical Thinking Skills. Asian Social Science, 7, 4, $26-35$.

[30] Zane, T. (2013). Implementing Critical Thinking with Signature Assignments. Salt Lake Community College, Spring.

\section{AUTHOR'S BIOGRAPHY}

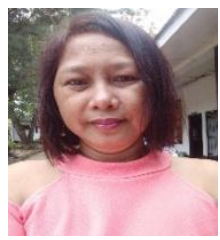

Scarlett O'Hara D. Sanchez is the Liberal Arts Department Head of Misamis University, Oroquieta City. She earned her Master of Arts in Education major in English Language Teaching from Misamis University, Ozamiz City.She is a candidate of Master of Arts in English Language at Xavier University-Ateneo de Cagayan, Philippines. 


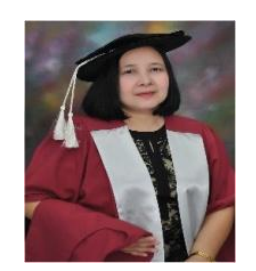

Maria Luisa S. Saministrado is Professor of English Language and Literature. A researcher, book reviewer, LET and IELTS reviewer, and literary criticism editor, she earned her PhD in English (2015) from the University of Newcastle, Australia, and $\mathrm{PhD}$ in Education (2005) from Xavier University-Ateneo de Cagayan, Philippines. She is a former chair of the English Department and director of English Communication Development Institute. Serving in the undergraduate and graduate English programs for 36 years already, she has published two nonfiction books, several textbooks for students, and research papers in refereed journals.

Citation: Scarlett O'Hara Sanchez, Maria Luisa S. Saministrado. "Linguistic Ability and Critical Thinking of Undergraduate Literature Students”. International Journal of Humanities Social Sciences and Education (IJHSSE), vol 5, no.12, 2018, pp. 7-20. doi:http://dx.doi.org/10.20431/2349-0381.0512002.

Copyright: (C) 2018 Authors. This is an open-access article distributed under the terms of the Creative Commons Attribution License, which permits unrestricted use, distribution, and reproduction in any medium, provided the original author and source are credited. 